\title{
DA VERITÀ EFFETUTUALEÀ LIBERA LIBERTÀ OU CONFLITO E LIBERDADE EM MAQUIAVEL
}

\section{Rodrigo Chaves de Mello ${ }^{1}$}

\begin{abstract}
Resumo: Partindo do debate com o campo do Republican revival, este artigo tem por objetivo refletir sobre o significado do tema da liberdade no pensamento político de Nicolau Maquiavel. Defendendo que o pensamento de Maquiavel tem suas raízes em uma articulação entre a cultura trágica grega e a proposição de uma dinâmica política democrática, interpretaremos a liberdade como a resultante de um jogo que define as instituições políticas como locus de responsividade às demandas inauguradas pelos conflitos que estruturam a vida social.
\end{abstract}

Palavras-chave: Maquiavel. Conflitos Sociais. Liberdade.

No capítulo XV d'O príncipe, se não o mais importante, certamente seu mais famoso escrito, Nicolau Maquiavel nos apresenta uma das mais centrais figuras argumentativas presentes em seu método de análise política. Diz-nos:

Mas, sendo minha intenção escrever algo de útil para quem por tal se interesse, pareceu-me mais conveniente ir direto à verdade efetiva das coisas, do que à imaginação dos mesmos, pois muitos conceberam repúblicas e principados jamais vistos ou conhecidos como tendo realmente existido. Em verdade, há tanta diferença de como se vive e como se deveria viver, que aquele que abandone o que se faz por aquilo que se deveria fazer, aprenderá antes o caminho de sua ruína do que o de sua preservação. (MAQUIAVEL, 1979, p. 62)

Contra as concepções idealistas predominantes entre teólogos, escolásticos e moralistas que procuravam fiar a existência do político em projetos metafísicos desenhados em torno de um ideal regulador de comunidade, o

1 Professor do Curso de Ciências Sociais da Universidade Estadual Vale do Acaraú (UEVA) e membro dos grupos de pesquisa "Anticapitalismo e Sociabilidades Emergentes" e "Democracia, Instituições e Participação Social”. E-mail: rodrigo.chaves.mello@gmail.com 
pensador florentino lança as bases de seu realismo ao propor a investigação dos assuntos políticos a partir da busca por sua verità effettuale. Nesse caminho, Maquiavel nos apresentará a perspectiva de uma práxis política que, tendo por eixo dinâmico as dimensões da ação e do conflito, se articulará em torno da proposição da liberdade. Com efeito, ao lermos Maquiavel, procuraremos explicitar o seu radical e original projeto de pensar o político não a partir de um ideal de regulação institucional, mas sim o deslocando para o terreno no qual estabelecerá uma tensa e criativa relação com o horizonte maior da liberdade. Nessa esteira, teceremos as linhas abaixo em torno do objetivo de identificar os elementos de sua obra que nos apontem uma perspectiva do político que, longe de desprezar o conflito e a multiplicidade de interesses que atravessam o campo do populo, toma-os como elementos propulsores de uma linguagem política voltada ao elogio da liberdade.

Assim, dialogando no interior do campo do chamado republican revival, que já há algumas décadas opera em torno da obra do secretário florentino, cabe-nos dizer que, longe da ambição de querer propor uma visada inédita sobre a obra, procuraremos nos beneficiar de alguns dos debates já produzidos no interior desse campo para avançarmos em nosso argumento.

Como bem observou Ricardo Silva (2008), o atual investimento republicano em torno do pensamento de Maquiavel vem logrando forte sucesso não apenas por renovar as interpretações do autor, harmonizando, com mais fidelidade, as suas ideias ao seu contexto de florescimento, mas também porque, ao fazê-lo, encontra em sua obra um farto repositório de munição contra as perspectivas liberais postas no debate político contemporâneo ${ }^{2}$. Todavia, como em um quadro impressionista que perde a clareza de seus contornos na medida em que dele nos aproximamos, internamente, esse campo de reflexões se encontraria longe de nos oferecer uma perspectiva consensual acerca do que significaria o republicanismo de Maquiavel.

É preciso reconhecer que o consenso negativo que une os neo-republicanos contra o pensamento liberal dominante revela-se frágil tão logo é transcendido o momento da crítica do modelo liberal e se inicia o momento da afirmação do modelo republicano. Observando os diferentes enquadramentos que os neorepublicanos dão a conceitos centrais, como o conceito de liberdade, bem como

2 Nessa visada em que Maquiavel se reatualiza aos dias atuais como um autor de combate, Silva (2008), em uma paródia a Quentin Skinner, provocativamente propõe que ao analisarmos o campo do republican revival, mais importante do que perguntarmos o que o florentino estava fazendo quando escrevia seus textos, seria questionarmos "o que os historiadores e teóricos neo-republicanos estão fazendo ao interpretarem a herança de Maquiavel” (SILVA, 2008, p. 4). 
seus desacordos quanto à natureza do acervo institucional adequado a uma república bem ordenada, o analista é levado à conclusão de que está tratando de uma disputa entre diferentes fórmulas políticas que recorrem à longa e multifacetada tradição republicana. No caso em apreço, esta disputa pela tradição desenrola-se de um modo ainda mais interessante, uma vez que as diferentes vertentes neo-republicanas aqui evocadas apoiam-se na obra do mesmo autor. (SILVA, 2008, p. 5)

Segundo a sugestão de Silva (2008), os debates atuais em torno dos motes republicanos de Maquiavel orbitariam em torno de três vertentes principais, cada uma delas indicando, mais ou menos abertamente, determinados posicionamentos políticos e direcionamentos normativos para se pensar os modelos de organização das instituições políticas nas sociedades democráticas contemporâneas. Tendo em John Pocock seu principal expoente, a primeira vertente advogaria o núcleo do pensamento maquiaveliano em torno de um alinhamento de suas ideias com as proposições aristotélicas, o que culminaria na defesa de um ideal positivo de liberdade. Em sentido distinto, e tendo em Quentin Skinner a sua figura central, a segunda vertente, deslocando-se do ideário grego para o ideário romano, procuraria demonstrar que a ideia de liberdade em Maquiavel, longe do polo positivo, melhor se coadunaria com uma definição enquanto liberdade negativa, não identificada, contudo, com a concepção liberal. Finalmente, a terceira concepção, vindo à tona a partir de trabalhos recentes de John McCormick, procurará enfatizar o elemento ferozmente democrático presente no republicanismo maquiaveliano.

Examinemos, en passant, os principais elementos de cada uma dessas vertentes, procurando, através deste expediente, oferecer um mapa a partir do qual possamos melhor nos guiar na interpretação da obra de Maquiavel.

Segundo os marcos da primeira linhagem interpretativa, Maquiavel teria atingido sua maturidade intelectual ao longo de seus anos de exílio, em um intenso e sistemático contato com a literatura dos clássicos gregos e também dos humanistas do renascimento italiano do século XV. Nesse período, Maquiavel iniciaria o processo no qual, ao recorrer às ideias do passado, projetaria suas concepções políticas para o futuro. Aqui, o principal legado que os clássicos da antiguidade forneceriam para o humanismo do renascimento italiano, no qual Maquiavel teria se embebido, seria a perspectiva de que apenas na participação dos assuntos públicos, os indivíduos - qua cidadãos realizariam sua potencialidade humana. Conforme essa definição da vida como vita activa et politica, a criação do social encontraria seu fundamento no 
desenvolvimento de um espírito transclassista de devoção e sacrifício político que demarcaria o terreno da polis enquanto palco por excelência para a realização da virtude humana, nos móbiles de um vivere civile. Sob essa embocadura, ganharão destaque as interpretações que o historiador neozelandês John Pocock estabelecerá acerca daquilo que originalmente denominou de momento maquiaveliano:

O Momento Maquiaveliano é uma expressão a ser interpretada de duas maneiras. A primeira denota o momento e a maneira em que o pensamento maquiaveliano fez a sua aparição. (...) no segundo, o momento maquiaveliano denota o problema em si. É o nome para o momento de conceitualização do tempo no qual a república parecia confrontar a sua própria finitude temporal, como tentativa de permanecer moral e politicamente estável em um fluxo de eventos irracionais concebidos como essencialmente destrutivo de todos os sistemas da estabilidade secular. Na linguagem desenvolvida para este propósito, isso foi dito como a confrontação da virtude com a fortuna e corrupção. (POCOCK, 1975, p. vii-viii) $)^{3}$

Segundo as seminais interpretações de Pocock ${ }^{4}$, o conceito de virtude seria aquele que com mais relevo se destacaria na obra de Maquiavel. Diante de seu confronto com a fortuna - signo contingencial e indelével de caracterização dos fenômenos políticos - e a corrupção - inevitável resultado da corrosiva ação do tempo sobre os ordenamentos das estruturas políticas -, a virtude se conceberia como a capacidade tipicamente humana em responder, de modo criativo, aos reveses presentes nos insondáveis horizontes dos assuntos que tangem a natureza das coisas políticas. Todavia, segundo a percepção de Pocock, a virtù não deve ser entendida como um exercício puramente individual. Ao contrário, estando sob seu turno a identificação do homem com o cidadão, a virtude se definiria como exercício coletivo operado na associação dos cidadãos em favor da res publica. Assim, mesmo que em sentido contrário a seus interesses

3 Livre tradução do autor. (N. do E.)

4 Uma terceira dimensão que Pocock tentará abarcar sob o conceito de momento maquiaveliano, e a qual destinará toda a segunda parte de seu livro, será a de sua continuidade histórica. Segundo Pocock, os ideais republicanos vicejados no contexto do renascimento florentino desdobraram-se em um processo de autoconsciência histórica que comporia o percurso do pensamento ocidental do cristianismo medieval até os momentos decisivos de conformação do mundo moderno. Nesse sentido, conceitos como o de equilíbrio entre poderes governamentais, as dinâmicas entre a virtù e a corrupção e o papel do exército e da propriedade na formação da personalidade cívica, dilataram-se no tempo e se fizeram presentes, enquanto uma linguagem política viva, tanto nos debates entre os revolucionários ingleses do século XVII, encontrando uma síntese especial na figura de James Harrington, quanto nos séculos XVIII e XIX entre os principais personagens do federalismo norteamericano. 
particulares, a definição da virtude cívica se daria pela capacidade dos indivíduos mobilizarem suas energias acionais em conformidade com o interesse público.

É nesse ponto que Pocock, em uma leitura francamente aristotélica de Maquiavel, aponta a república - qua politeia - enquanto uma estrutura de virtude ("structure of virtue"), ou ainda, enquanto um locus no qual a realização do bem comum se afirmaria como precondição para a fruição de todos os outros bens. Nesse sentido, pelo móvel da virtude, os cidadãos particulares, ao agirem em nome do bem público, realizariam sua própria essência universal. Sobre esse ponto, Pocock (1975, p. 68) nos esclarece:

Mas todos os cidadãos não eram idênticos; se assemelhavam qua cidadãos e seres universais, mas eram diferentes como seres particulares; cada um tinha suas próprias prioridades no que diz respeito aos bens particulares que escolhia poder perseguir, e, assim, encontravam-se em categorias específicas com quem compartilhavam uma, algumas ou todas de suas prioridades. Assim, a polis se encontrou face ao problema de alocar as prioridades, determinando quais bens particulares, e em qual momento, poderiam ser desfrutados por aqueles que lhes tinha dado prioridade, embora a determinação desse problema fosse claramente tarefa dos cidadãos. Aristóteles não acreditava que o indivíduo enquanto cidadão, engajado na atividade universal de buscar e distribuir o bem comum, devesse ser considerado fora da relação com o mesmo indivíduo envolvido na atividade particular de buscar e desfrutar dos bens particulares que eles preferiam. Desde a definição do cidadão enquanto quem governa e é governado, a atividade dirigente conjuga-se com a atividade em relação ao qual ele é subordinado. Universal e particular se encontraram no mesmo homem e, se o cidadão assume uma personalidade social particular como resultado de busca, desfrutando e se destacando na realização dos valores particulares que ele preferia, esta deve modificar a sua capacidade de se engajar na atividade universal de tomar decisões destinadas a distribuir o bem comum. O problema agora enfrentado pela polis se tornou o da distribuição do exercício particular desta função universal em uma forma relacionada com a diversidade da personalidade social que os cidadãos exibiam como resultado de seus valores individuais prioritários. ([grifo nosso])

Nessa visada, sob os auspícios da estrutura da virtude republicana, espaço de síntese entre o particular e o universal a partir da ação do cidadão na polis, Maquiavel centraria sua preocupação em propor uma ordem institucional apta a gerar, no campo público, um equilíbrio entre as prioridades dos diversos setores sociais. Assim, por intermédio de uma estrutura institucional mista, a boa ordem de governo seria aquela na qual nenhum setor social poderia se sobrepor aos interesses dos demais, nem tampouco deles prescindir. É nesse 
ponto que Pocock identifica a importância que o tema da cidadania militar ocuparia no pensamento maquiaveliano, por ser justamente através da mobilização desse expediente que poderíamos visualizar a passagem da massa popular à uma comunidade de cidadãos ativos. Estando confiada ao povo a "guarda da liberdade" em uma república expansiva, como no exemplar caso romano, o patriótico ato de defesa dos bens comuns seria visto como um adequado vetor para a generalização, junto ao cidadão comum, dos elementos de socialização com a cultura cívica necessariamente requerida para a estável perpetuação da boa ordem republicana ${ }^{5}$. Assim sendo, encontramos, aqui, o alfa e o ômega do enraizamento daquilo que a teoria política moderna fará conhecido sob o conceito de liberdade positiva.

É em reconhecimento às veredas abertas a partir das interpretações ofertadas por Pocock, que a segunda vertente de interpretação do legado republicano de Maquiavel se desenvolverá, tendo em Quentin Skinner o seu principal expoente.

Skinner vem recuperando a tradição republicana em moldes distintos daqueles propostos por Baron e Pocock, apresentando sua interpretação como extensiva ao pensamento de Maquiavel. Para Skinner, o renascimento do republicanismo nos primórdios da modernidade deveu-se mais à recuperação de moralistas romanos como Cícero e Salustio do que à retomada da concepção aristotélica das virtudes cívicas. É certo que nos estudos de Baron e Pocock os referidos pensadores romanos aparecem recorrentemente. Contudo, eles aparecem como seguidores da concepção aristotélica de cidadania. O que Skinner sustenta é que o republicanismo romano, embora não alheio à concepção grega de cidadania, deve ser pensado como uma tradição intelectual e política independente. Se na interpretação cívico-humanista o centro das atenções era a noção de virtude cívica, na interpretação neo-romana de Skinner o foco de análise desloca-se para a arquitetura institucional do Estado. (SILVA, 2008, p. 15)

Esse deslocamento, proposto por Skinner, demandará uma redefinição acerca das bases implicadas na concepção de liberdade. Procurando minimizar as consequências comunitaristas advindas do foco no modelo neo-ateniense, Skinner lançará mão de uma perspectiva polêmica ao propor que, ao falar em liberdade, o pensador florentino tinha em mente as suas circunscrições negativas. Conforme essa visada, a liberdade desfrutada tanto por agentes coletivos quanto individuais se definiria pela possibilidade de ambos

5 Dedicaremos, na sequência do texto, espaço para abordarmos, de forma mais paciente, a relação proposta por Maquiavel entre cidadania militar, cultura cívica e liberdade. 
perseguirem os fins por eles mesmos escolhidos. Nesse sentido, ser livre seria fundamentalmente o estado daquele que, ao agir, não se encontra constrangido pelo livre concurso de nenhum outro agente, podendo, justamente por isso, conduzir-se segundo sua própria vontade e julgamento. Todavia, há que se destacar que, ao operar esse deslocamento, Skinner não pretende, contudo, identificar a visão de liberdade negativa em Maquiavel com as encontradas na moderna concepção liberal atomista, sendo enfático em afirmar que a realização da liberdade dos particulares somente pode vicejar em uma comunidade de homens livres, logo, em um contexto no qual a liberdade individual não exclua a liberdade política ${ }^{6}$.

Segundo Skinner, no contexto do humanismo cívico, o republicanismo de Maquiavel teria cores heterodoxas, pois suas perspectivas introduziriam uma série de inovações que acabariam por distingui-lo do republicanismo clássico. Entre essas, a que mais fortemente teria marcado o caráter sui generis de suas ideias seria o elogio dedicado ao papel dos conflitos sociais na ordem republicana. Contra a tendência dos humanistas em enxergarem os conflitos sociais como fonte de ameaça à liberdade coletiva e à ordem pública, ao analisar a história de Roma, Maquiavel os apropria como fator causal do aperfeiçoamento das instituições políticas e, portanto, enquanto força motriz de alargamento das liberdades. E esse é um ponto central para a abordagem skinneriana, que estabelecerá o cerne do republicanismo maquiaveliano no estabelecimento de um circuito no qual os conflitos resultariam em boas leis e estas, por sua vez, resultariam na ampliação da liberdade. Assim, Skinner inclina-se a ver em Maquiavel o apelo a certa ordem institucional que seja capaz de conter, ou no mínimo neutralizar, os riscos da degeneração dos conflitos em tendências à corrupção. Nesse sentido, repousaria sobre os ordenamentos constitucionais da república a dupla, mas complementar, função de conter os comportamentos corruptos e de induzir a comportamentos virtuosos advindos de um conflito bem compreendido.

Por um lado, as leis republicanas bloqueiam a tendência à corrupção dos setores sociais mediante a promoção do equilíbrio de poder entre tais setores. $\mathrm{Na}$

6 Sobre esse ponto, Silva identifica um movimento duplo em Skinner: "por um lado, contra os modelos liberais, Skinner afirma que a postulação de uma completa desvinculação entre liberdade individual e liberdade política representa uma grave falha de racionalidade. Seria como desejar os fins sem recorrer aos meios. Contra os modelos comunitaristas, por outro lado, Skinner afirma que a participação política é precisamente um meio, um instrumento da liberdade, não a própria liberdade. Em relação à liberdade, a participação política seria um valor instrumental, não um valor intrínseco, como quer o modelo neo-ateniense." (SILVA, 2008, p. 16). 
medida em que o povo e as elites, com seus diferentes humores, estivessem adequadamente representados nas instituições do Estado republicano, cada um desses setores tenderia a exercer uma espécie de vigilância sobre o outro. Como seus respectivos humores são não apenas diferentes, mas também antagônicos, a vigilância mútua tenderia a servir de antídoto à ociosidade do povo e a arrogância das elites. Por outro lado, a lei também teria a função de canalizar o comportamento dos cidadãos para atividades conducentes à realização do bem comum. Num sentido, [Skinner] recupera aqui a tese de Rousseau de que os cidadãos devem ser forçados a ser livres. (SILVA, 2008, p. 20)

A luz dessa interpretação, fica-nos patente que a abordagem republicana de Skinner termina por desaguar em um apelo juridicizante das relações políticas, pois se o silêncio da lei corroboraria a tendência dos diversos setores sociais à corrupção, sobre as instituições republicanas se depositariam os votos para a canalização e a condução, em equilíbrio, das contendas que atravessam o tecido social, lançando-as, assim, do terreno dos vícios ao campo público das virtudes.

Finalmente, como uma espécie de radicalização do ponto neorrepublicano, encontramos a terceira vertente de interpretação dos sentidos do republicanismo maquiaveliano. Essa vertente vem sendo vocalizada pelos recentes trabalhos empreendidos por John McCormick. Segundo esse intérprete, tanto as abordagens propostas por Pocock, quanto as oferecidas por Skinner mostram-se insatisfatórias para pensarmos o núcleo central da problemática maquiaveliana, pois ambas compreenderiam mal a sociologia dos conflitos de Maquiavel, o que resultaria em uma leitura superficial, e, no limite, equivocada, das implicações constitucionais trazidas à baila por sua concepção de liberdade. Segundo McCormick (2003), essa má compreensão teria raízes em uma certa uma tendência aristocrática - não apenas exclusiva aos historiadores de Cambridge - vigente no movimento de retorno ao republicanismo, que seria fortemente estranha e não faria jus à natureza essencialmente democrática presente no ideário político de Maquiavel.

Concluo, resumindo como os estudiosos de Cambridge inclinam-se a interpretar Maquiavel de forma a enfatizar artificialmente a sua conformidade com o republicanismo convencional: especificam insatisfatoriamente o conflito de classes, em sua teoria, resultando por ignorar os meios institucionais através dos quais o povo tornou as elites responsivas, forçando-as a prestarem contas; os estudiosos de Cambridge associam a animação da participação popular no pensamento maquiaveliano, primeiramente, com conquista militar em oposição às políticas domésticas; de maneira pouco apropriada, igualam suas críticas à nobreza com as críticas ao povo, comprometendo, assim, o papel proeminente 
que Maquiavel atribui ao povo como "guardiões da liberdade"; concentram em suas definições abstratas de liberdade as expensas de recomendações de políticas específicas de Maquiavel sobre como mantê-la; os estudiosos de Cambridge usam Maquiavel para formular a definição de liberdade que é oposta à opressão política de vários tipos, mas que é atualmente frágil com respeito à dominação social; e eles permanecem em grande parte em silêncio sobre as formas de dominação doméstica do povo pelas elite, que foram totalmente consonantes com a teoria republicana e, muitas vezes, perpetradas na prática republicana. (McCormick, 2003, p. 636)

A crítica que McCormick dirige aos estudiosos de Cambridge reside no fato de - ao analisarem, no interior da obra do florentino, o papel desempenhado pelos conflitos sociais na manutenção da liberdade - tenderem a nivelar como idênticas as contribuições dos respectivos setores em litígio. Sob esta perspectiva, seus estudos se inclinariam a visualizar, sob o prisma do equilíbrio, o jogo entre os diferentes humores postos em interação na vida da república, jogo que terminaria por encontrar seu ponto optimum nas leis e nas instituições. Assim, segundo McCormick (2003), mais do que se dirigir às fontes de uma conflituosidade bem-compreendida, o que o exame de Maquiavel nos revelaria seria a disputa entre segmentos sociais irreconciliáveis no campo dos interesses e assimétricos no campo da força. Se o que definiria os grandi seria a irrefreável ambição de seu projeto dominador e expansionista, o populo se definiria pelo desejo de não ser dominado, o que os inclinaria a mobilizar todos os meios e recursos para, na medida do possível, manter sob controle a sanha das elites. Por essa via, McCormick (2003), ao analisar em especial o papel político desempenhado pela instituição pública do Tribunato, identifica na ferocidade do povo em controlar as elites, o desenvolvimento de níveis de accountability, que nos indicariam as tendências pró-plebeias de Maquiavel, como também nos autorizariam a enraizar sua obra no interior do campo democrático.

Traçados os contornos do mapa a partir do qual o debate contemporâneo vem procurando reabilitar os conteúdos republicanos presentes na filosofia política de Maquiavel, propomos lançar algumas breves interpretações sobre sua obra, tentando, a partir de sua filosofia da ação, compreender o papel, por ele destinado, da relação entre os conflitos sociais e a liberdade. Ao longo deste percurso, tentaremos visualizar em Maquiavel o descortinar de uma arquitetura política que, distinta dos cânones programáticos da matriz jurídica, teria no movimento espontâneo de composição das forças sociais o seu principal vetor, podendo, por tal razão, a esse movimento subordinar o campo da legislação. 
Sob orientação do professor Cícero Araújo, em tese recentemente defendida no interior do Programa de Pós-graduação em Ciência Política da Universidade de São Paulo, Jean Gabriel Castro da Costa (2010) aponta a necessidade de pensamos Maquiavel a partir de uma filiação com o horizonte da cultura trágica grega pré-socrática. Acreditamos, junto com Jean Costa, que essa perspectiva possa nos apresentar uma via fecunda para, deslocando-nos do debate entre o comunitarismo das interpretações dos neoatenienses e o institucionalismo das abordagens neorromanas, apreciarmos a radicalidade do pensamento político de Maquiavel em uma original articulação entre ação política, liberdade e conflito social.

Buscando, em poetas como Homero e Hesíodo, referências do universo cosmológico da religião pagã, em sua investigação, Jean Castro salienta alguns aspectos marcantes e estruturais de organização da cultura trágica antiga. É assim que, iniciando seu argumento, nos chama atenção para a compreensão da importância de que, no interior da cosmogonia grega, o universo teria se criado em torno de quatro deuses ${ }^{7}$ que, interagindo entre si, como em um jogo, estabeleceriam os contornos cosmológicos da realidade. Primogênito, Caos permaneceria soberano em seu poder mesmo após o nascimento dos demais e, enquanto deus intempestivo e avesso à lógica da ordenação cosmológica, continuando a reinar nas recônditas profundezas do mundo, irrompendo, vez ou outra, a superfície para, pondo ao chão das mais belas paisagens ao mais justo dos homens, desconcertá-la, seja na forma de catástrofes súbitas, acidentes involuntários ou pestes danosas. Assim, desprovendo o cosmos de sua previsibilidade plena, Caos, com a fúria significativa de seu acaso, relativizaria a necessidade dos eventos regulares e inevitáveis (nascimento, morte, corrupção de todas as coisas, etc.), propondo o desenrolar da realidade enquanto um movimento alheio a qualquer horizonte de finalidade última ou de justa

7 Sobre o evento cosmogônico, oferece-nos Hesíodo um belo retrato em linhas na Teogonia: "Sim bem primeiro nasceu Caos / depois também Terra de amplo seio, de todos sede irresvalável sempre, dos imortais que têm a cabeça do Olimpo nevado, / e Tártaro nevoento no fundo do chão de amplas vias, / e Eros: o mais belo entre Deuses imortais, solta-membros, dos Deuses todos e dos homens todos ele doma no peito o espírito e a prudente vontade. Do Caos Érebos e Noite negra nasceram. / Da Noite aliás Éter e Dia nasceram, gerou-os fecundada unida a Érebos em amor. / Terra primeiro pariu igual a si mesma Céu constelado, para cercá-la toda ao redor e ser aos Deuses venturosos sede irresvalável sempre. / Pariu altas Montanhas, belos abrigos das Deusas ninfas que moram nas montanhas frondosas./ E pariu a infecunda planície impetuosa de ondas o Mar, sem o desejoso amor./ Depois pariu do coito com Céu: Oceano de fundos remoinhos e Coios e Crios e Hipérion e Jápeto e Téia e Réia e Têmis e Memória e Febe de áurea coroa e Tétis amorosa./ E após com ótimas armas Crono de curvo pensar, filho o mais terrível: detestou o florescente pai." (HESÍODO, 1995, p. $111)$. 
redenção transcendental. Sob esse registro, o real, enquanto movimento en train de se faire, se definiria sob um fluxo sem telos ${ }^{8} \mathrm{e}$, portanto, estranho a qualquer pretensão unidimensional de verdade.

Diante deste cenário, não encontrando conforto pacificador em fugas ao transcendente, a cultura trágica se caracterizaria por uma percepção do tempo enquanto processo de negociação existencial com o abismo ${ }^{9}$. Seja em termos de bem, bom, belo, ou justo, ao considerarmos a ausência de qualquer fundamento último a reger e significar aquilo que é, deparamo-nos com a imagem de um cenário de composição social estruturado em torno do mais radical pluralismo $^{10}$. Nesse sentido, a dimensão da tragédia vicejará ao refletir, especularmente, no campo da cultura, as dinâmicas de uma paisagem social

8 Acerca dessa dimensão, são exemplares alguns fragmentos de Heráclito: "O mesmo é vivo e morto, acordado e adormecido, novo e velho, pois estes, modificando-se, são aqueles e, novamente, aqueles, modificando-se, são estes" (Fragmento XLII); “Transmutando-se, repousa” (Fragmento XLIII); "Nos mesmos rios entramos, somos e não somos" (Fragmento XLIX); "Não é possível entrar duas vezes no mesmo rio" (Fragmento L); "Aos que entram nos mesmos rios, afluem outras e outras águas. E os vapores exalam do úmido" (Fragmento LI); "Recordar-se também do que esquece por onde passa o caminho" (Fragmento CIII); "O tempo é criança brincando, jogando: reinado da criança" (Fragmento CXXXI)” (COSTA, 2002, p. 204 -218).

9 Sobre esse aspecto da cultura grega, em um belo artigo ao jornal Folha de São Paulo, de 29 de fevereiro de 2001, intitulado A descoberta do Abismo, Cornelius Castoriadis nos diz: "A experiência ou afirmação ontológico-afetiva dos gregos - é a descoberta, o desencobrimento do Abismo; certamente reside aí o 'núcleo' da ruptura e, sem dúvida nenhuma, sua significação absoluta, transistórica, seu caráter de verdade doravante eterna. Aqui, a humanidade sobe em seus próprios ombros para olhar mais além de si mesma e olhar-se a si mesma, constatar sua inexistência - e se põe a fazer e a se fazer. Banalidade que convém repetir com força porque constantemente esquecida e recoberta: a Grécia é primeiro e antes de tudo uma cultura trágica. As pastorais ocidentais imputadas à Grécia nos séculos XVII e XVIII assim como os comentários profundos de Heidegger coincidem, desse ponto de vista. [...] O que faz a Grécia não é a medida e a harmonia nem uma evidência da verdade como 'desvelamento'. O que faz a Grécia é a questão do não-sentido e do nãoser. Isso é dito claramente desde a origem - mesmo se os ouvidos tapados dos modernos não podem ouvi-lo ou somente o ouvem por meio de suas consolações judaico-cristãs ou de seu correio sentimental filosófico. A experiência fundamental grega é o desvelamento, não do ser e do sentido, mas do não-sentido irremediável. Anaximandro o diz, e em vão se glosaria eruditamente a frase para obscurecer sua significação: o simples existir é 'adikia, 'injustiça', desmedida, violência. Pelo simples fato de existirmos, ultrajamos a ordem do ser - que é portanto, do mesmo modo, essencialmente ordem do não-ser. E diante disso não há recurso algum, nenhuma 'consolação' possível. A mó da 'diké' [Justiça] impessoal esmaga, incansavelmente, tudo o que vem a ser. [...] Mas esse primeiro fundamento já contém um outro componente decisivo dessa apreensão imaginária do mundo: a universalidade. Sabemo-lo, mas Hannah Arendt fez bem em nos lembrar: na 'Ilíada', não há nenhum privilégio dos gregos em relação aos troianos e, na verdade, o herói mais humano, o mais comovente, é Heitor, e não Aquiles - Heitor que sofre um destino radicalmente injusto e é enganado por uma deusa (não qualquer uma: Atena) no momento mesmo em que vai morrer." (CASTORIADIS, 2004).

10 Ao escrever sobre Nietzsche, o mais trágico entre os pensadores modernos, Deleuze nos diz que "A afirmação múltipla ou pluralista da existência é a essência do trágico.” (DELEUZE, 2001, p. 28). 
que, atravessada por conflitos e disputas, dispensará a sua redução em denominadores morais que, de forma maniqueísta, pudessem assinar o fato do pluralismo em torno de um jogo entre o bem e o mal. Longe da redução maniqueísta, o que encontramos é um cenário muitas das vezes operado em torno da confrontação de juízos éticos condicionais - como aquele desenhado por Sófocles ao confrontar as razões de Antígona com as de Creonte - em que o gládio se dá entre polos igualmente justos, em uma disputa digna do direito contra o direito, ou ainda do certo contra o certo ou do bem contra o bem.

Nesse contexto, no qual aquilo que existe, existe naturalmente no fluxo de seu sendo, o conflito se mostrará enquanto dimensão criativa de um mundo plural, pois por seu intermédio, não apenas manifesta a condição plural da humanidade, como também a mantém e a reatualiza, na medida em que, pelo expediente agonístico, encontramos uma chave para minimizar os riscos da dominação de um único ponto de vista. O conflito produziria, dessa forma, a abertura da realidade a uma tensão produtiva. Assim, nessa arena ontológica e esteticamente conflitiva, a melhor medida para uma vontade será revelada por outra vontade igualmente forte e a ela contraditória.

Para tanto, como se sabe, os gregos promoviam espaços para a disputa em diversas esferas: competições esportivas, competições artísticas de diversos tipos, disputas em forma de diálogo no centro das peças teatrais, disputas políticas na Ágora, onde a palavra era um importante instrumento de disputa que faria emergir líderes talentosos para a pátria. Nietzsche interpreta a instituição do ostracismo como um instituto destinado a garantir a manutenção da disputa política. Quando um cidadão adquiria proeminência exagerada de modo a adquirir poder suficiente para obter a tirania e encerrar a disputa, ao eliminar os adversários, havia a possibilidade de condená-lo ao ostracismo. Nietzsche cita o exemplo dos efésios que ao banirem Hermodoro, teriam dito: Entre nós ninguém deve ser melhor; se alguém o for, todavia, então que seja em outra parte e na companhia de outros. (COSTA, 2010, p. 40)

Nessa chave positiva, o conflito é em si mesmo visto como fonte de racionalidade social. Longe de algo deletério ou corruptor a ser superado, em seu próprio movimento o conflito apresenta a sua razão de ser, pois, guardião da multiplicidade, afasta os riscos tirânicos do domínio de um só, instituindo, doravante, as bases de proteção ao florescimento do pluralismo. Num universo sem o porto seguro e sem a cúmplice estabilidade do transcendente, a arena do conflito se converte em uma zona de promoção de equilíbrio para um mundo, por definição, instável. 
Despedindo-se da noção de verdade última das coisas, os partícipes desse universo entendem a si mesmos em sua própria limitação, estando a eles vedado o pleno conhecimento de suas ações e o controle das consequências de seus atos. Estranho a ideia daquilo que modernamente conhecemos como ego, o indivíduo antigo não se define como o centro de suas decisões, mas, longe disso, vê-se conformado pelo eterno jogo entre ethos (forças internas a ele e que, lidas no registro da physis, repercutem em suas ações) e daimon (forças externas e que afetam seu destino). Sobre este terreno, encontramos a dignidade do tema da ação em sua correlação com o horizonte da liberdade. Pois, mais do que a resultante de uma escolha racional que teria por fundamento o livre arbítrio, a ação aqui é vista como a afirmação da necessidade primeira que implica na própria afirmação da vida e do valor do indivíduo que age. Corajoso enfrentamento ao destino, antes de tudo e acima de qualquer coisa, a ação se define enquanto ato de necessidade ontológica. E sendo o destino insondável, a ação carrega consigo, intrinsecamente, o valor de um salto no escuro através do qual se estabelece o flerte com o abismo da existência, tentando sobre ele alçar uma ponte para o futuro. E nesse caminhar entre brumas, o agir se define como a via, por excelência, para a experimentação e afirmação da liberdade. Como nos mostram as páginas das tragédias gregas, o verdadeiro herói não é aquele que necessariamente ganha, mas sim aquele que, agindo, necessariamente, enfrenta seu destino e, ainda que venha a cair, vai ao chão com a dignidade própria a virtude de sua performance.

Diante dessa pedagogia trágica que ensina a liberdade vis-à-vis a certa dureza de caráter capaz de suportar o fluxo da necessidade e os riscos inerentes à ação, parecem-nos precisos os dizeres de Jean Costa:

Mas negar a necessidade, em nome da ausência de sofrimento, só seria possível buscando uma pacificação total que levaria a uma neutralização da vida, dos impulsos vitais, das paixões e de tudo aquilo que produz, também, alegria. Condenar este mundo da necessidade levaria à perda da liberdade, entendida como neutralização da vida. Na perspectiva trágica, a aceitação do fluxo da necessidade, fonte de sofrimento e alegria, seria uma libertação, uma afirmação da vida inteira, com suas alegrias e sofrimentos. Os obstáculos são vistos como um exercício de aprimoramento, como oportunidade para o aumento da força, quer dizer, da vitalidade. Nessa chave, o conflito e a disputa adquirem importância peculiar, pois o adversário oferece resistência, permitindo com isso o aumento da força. O total domínio de um só, eliminando o adversário, eliminaria a disputa, a resistência, a medida e, com isso, viriam a hybris e a decadência. Portanto a política deve ser pensada como arena para a disputa, e as instituições pensadas 
para manter a tensão criativa entre adversários. Apenas assim é que a política apareceria umbilicalmente associada à liberdade. (COSTA, 2010, p. 102 [grifo nosso])

Nesse sentido, ao mobilizarmos a dimensão da cultura trágica como pano de fundo para o desenvolvimento das concepções maquiavelianas, acreditamos poder lograr um terreno fértil para, com mais acuidade, visualizarmos a importância que os temas da ação política, dos conflitos sociais e da liberdade desempenham no interior da obra do pensador florentino. Em nossa hipótese, será por intermédio da articulação entre esses pontos que poderemos encontrar, nessa obra, a abertura de uma via possível para percorremos os contornos políticos de uma organização social antijurídica.

Ao abrir o capítulo três de seu Discorsi, Maquiavel surpreende ao, com pretensão universal, apresentar a realidade de um desenho antropológico que estará sempre na base de todo e qualquer empreendimento político:

Como demonstram todos os que escreveram sobre política, bem como numerosos exemplos históricos, é necessário que quem estabelece a forma de um Estado, e promulga suas leis, parta do princípio de que todos os homens são maus, estando dispostos a agir com perversidade sempre que haja ocasião. Se esta malvadez se oculta durante um certo tempo, isso se deve a alguma causa desconhecida, que a experiência ainda não desvelou; mas o tempo - conhecido justamente como o pai da verdade - vai manifestá-la. (MAQUIAVEL, 1978, p. 29)

Esse é um ponto importante para a compreensão do argumento de Maquiavel, pois a partir da consideração da maldade inerente ao humano ${ }^{11}$, o florentino não apenas convidará a um olhar realista sobre o político, dele

11 O tema da maldade humana reaparecerá no vigésimo sétimo capítulo do Livro I, quando Maquiavel estudará o comportamento do tirano de Perúgia, João Paulo Baglioni, quando este, tendo a oportunidade de matar o papa Julio II, que marchava contra sua cidade, recuou diante das vestes sagradas e não o fez. "Do episódio se conclui que os homens não sabem guardar nenhuma dignidade no crime, nem ser perfeitamente bons. E que, quando o crime apresenta algum aspecto de grandeza ou generosidade, temem praticá-lo. [...] Por isto João Paulo - que não temia o incesto ou o parricídio - quando surgiu uma ocasião legítima, não soube fazer o que lhe teria valido a admiração de todos pela sua coragem, dando-lhe memória eterna. Não quis ser o primeiro a demonstrar aos chefes da Igreja a pouca estima que se tinha pelos que governam como eles, executando uma ação cuja grandeza teria feito apagar sua infâmia, neutralizando todos os perigos que dela pudessem resultar" (MAQUIAVEL, 1978, p. 95). Nessa passagem, fica-nos claro que, para Maquiavel, em termos políticos, o problema não é a maldade em si, pois muitas vezes é vizinha da virtude, mas sim o da maldade banal, incapaz de lograr grandezas. Como nos demonstra o exemplo do tirano de Perúgia, longe de uma crítica moralizante ao uso da força, o que vem à baila é a revelação de que o limite da política reside no uso medíocre que alguns homens fazem desse meio extraordinário. 
dispensando qualquer visada romântica que poderia nos conduzir à míope e irrefletida glorificação do oprimido, mas também a uma abordagem do político que, levando em consideração o caráter indelével da perversidade envolvida nos assuntos humanos, possa não ser desta refém, nem, tampouco, ser por ela instrumentalizada. É sobre esse registro que Maquiavel evocará o período subsequente à morte dos Tarquínios, mostrando a violência com que os nobres se lançaram contra o povo, derramando sobre este todo o veneno que guardavam no coração e agredindo-o com todas as vexações que podiam conceber (Maquiavel, 1978, p. 29), para concluir que o comportamento socialmente virtuoso somente pode sê-lo quando os homens se encontram submetidos a uma certa circunstância de fatores que os levem a agir para além de seus interesses pessoais. Nessa toada, nos dirá Maquiavel, se a fome e a miséria despertam no homem a operosidade, agindo sobre eles as leis podem torná-los bons ${ }^{12}$.

Todavia, partindo do dado da perversa natureza humana, Maquiavel não pretende nos apresentar uma concepção do político que venha a negá-la ou transformá-la - e neste ponto sua percepção se assemelha a de Hobbes. Ao contrário, em seu horizonte, não caberia ao político negar o movimento da perversidade, mas sim, tomando-o por fato incondicional, trazê-lo para o interior de uma determinada ordem institucional que não apenas seja moldada por este movimento, mas que também possa orientá-lo, transformando-o em fonte de energia para a promoção do maior dos bens públicos: a liberdade.

É assim que, indo em direção contrária à de toda tradição italiana que, de Dante aos humanistas, se apressava em demonstrar o papel negativo que as discórdias e tumultos engendravam na vida social, fazendo-a degenerar em barbárie, Maquiavel inovará ao propô-los, em chave positiva, como movimento fundamental ao florescimento da liberdade e da ordem institucional que a acompanha:

12 Sobre esse ponto, e o atualizando ao caso florentino, nos dirá Bignotto: "Em Maquiavel [...] as leis ocupam o lugar que os Tarquínios ocupavam enquanto vivos: o lugar do medo original da morte que faz com que os homens desejem algo além de seus interesses pessoais. O caso florentino mostra, no entanto, que a simples existência de leis não é a garantia da vitória do bem comum sobre os interesses individuais que caracteriza as grandes repúblicas. Florença tivera nos Médicis seus Tarquínios, mas fora incapaz de encontrar seu Brutus. A cidade permaneceu prisioneira dos interesses dos grupos, sem atingir a forma maior da organização humana que é a república. Sua evocação no capítulo anterior, que tanto nos surpreendera, parece, pois, destinada a demonstrar a importância de se tomar Roma como paradigma para o estudo da liberdade, uma vez que ela foi capaz de transformar o medo da morte, e o egoísmo natural dos homens, na melhor forma de organização" (BIGNOTTO, 1991, p. 84). 
Não aceitarei as afirmativas dos que acham que aquela [Roma] foi uma república tumultuada e desordenada, inferior a todos os outros governos da mesma espécie a não ser pela boa sorte que teve, e pelas virtudes militares que lhe compensaram os defeitos. [...] os que criticam as contínuas dissensões entre os aristocratas e o povo parecem desaprovar justamente as causas que asseguraram fosse conservada a liberdade de Roma, prestando mais atenção aos gritos e rumores provocados por tais dissensões do que aos seus efeitos salutares. Não querem perceber que há em todos os governos dois humores em oposição: o do povo e o dos grandes, e todas as leis que se fazem para proteger a liberdade nascem da desunião entre eles, como prova o que aconteceu em Roma, onde, durante os mais de trezentos anos que transcorreram entre os Tarquínios e os Gracos, as desordens havidas produziram poucos exilados, e mais raramente ainda fizeram correr o sangue. (MAQUIAVEL, 1978, p. 31)

Passando da imagem fictícia de uma sociedade idílica, voltada para a paz, para o elogio da sociedade tumultuária, Maquiavel avança de forma decisiva sobre o terreno do político. Aqui, o problema não mais será o da maldade humana, mas sim o da afirmação de que essa maldade não pode encerrar a possibilidade de constituição de bons ordenamentos institucionais. Deslocando-se da problemática antropológica ao campo do político, Maquiavel nos dará, pela imagem da guerra, a chave para a compreensão da liberdade enquanto horizonte que indica a reflexão sobre a política a partir de seu mínimo denominador, qual seja, a existência de desejos e humores postos em oposição na polis. Da luta entre os grandi e o populo, a liberdade não será apenas a resultante, mas o indicativo de uma sua solução possível a um movente e inesgotável conflito. Nesse sentido, mais do que uma solução permanente para as lutas internas à república, a liberdade se afirmará em um desenho político que, atravessado por forças que não podem ser plenamente satisfeitas, não deixa de buscar meios para exprimi-las.

Não existe, pois, em Maquiavel, um elogio cego dos conflitos, mas a busca da verdadeira origem da liberdade. [...] uma ruptura essencial com a tradição, acaba, no entanto, de se operar. Rejeitando a ideia de que a paz e a estabilidade são os objetivos de toda ação política, Maquiavel introduz não somente uma nova maneira de pensar a liberdade, mas uma nova forma de analisar a política. De um pensamento incapaz de criticar as indecisões dos homens públicos e que se contentava em afirmar a importância da concórdia, somos conduzidos a um universo em constante mutação de tal forma que a imagem de uma sociedade calma e prudente, tão cara aos humanistas, se evapora. (BIGNOTTO, 1991, p. 89) 
Pensando a política não a partir da utopia da paz, mas sim pelos movimentos capazes de fomentar e manter viva a liberdade, Maquiavel mais uma vez inovará, atentando agora contra as paisagens aristocráticas. Ao nos propor, no quinto capítulo dos Discorsi, a questão acerca de a quem deve a república confiar a guarda da liberdade, Maquiavel nos apresenta - como dirá McCormick - "sua preferência normativa pela república popular" (MCCORMICK, 2013, p. 270), aconselhando-nos a sempre confiar o depósito de algo valioso àquele que tem por ele menos avidez. Assim, tendo em mente os diversos humores e interesses que irreconciliavelmente definem os grandes e o povo, perceberemos nos primeiros, a sede de dominar e nos segundos o desejo em não ser dominado, e, portanto, uma vontade mais firme de viver em liberdade. Nesse sentido, destinando ao povo o papel de guardião da liberdade, “[...] é razoável esperar que cumpram com menos avareza, e que, não podendo apropriar-se do poder, não permitam que outros o façam [...]" (MAQUIAVEL, 1978, p. 33) ${ }^{13}$.

Nesse elogio franco ao campo popular e a seu ânimo pelo vivere libero, Maquiavel nos apresenta toda uma perspectiva do político enquanto movimento a operar sobre o movimento. Isso nos fica claro quando, aludindo às possibilidades sobre se seria possível instalar em Roma um governo que acabasse com as inimizades entre o povo e o senado, Maquiavel afirma que a busca pela pacificação teria como certo e inconveniente resultado a debilitação da república, de modo que, querendo acabar com a razão dos tumultos, acabariam, outrossim, com a razão da sua grandeza. Nessa conclusão, nosso autor nos chama atenção a um ponto fundamental, qual seja, a identificação entre a liberdade e a potência. Pensando a política sob os fluxos da contingência, e sem o socorro a um ideal regulador, ao falar da dinâmica das relações sociais que inauguram o movimento da liberdade, seu horizonte não nos parece ser o da defesa de uma forma institucional estabilizada, mas sim o de uma engenharia política dúctil que, atravessada pelas forças emanadas pelos conflitos sociais, seja capaz de permanentemente (re)criar as condições da

13 Sobre esse ponto, em sua interpretação democrática de Maquiavel, nos diz McCormick (2013, p. 257): "Maquiavel promove Roma à condição de modelo porque a entende como uma república de domínio popular. Diferentemente de outras repúblicas, Roma atribuía um papel especial às massas populares: o de guardiãs da liberdade. O povo é, em última instância, o árbitro da liberdade no regime. Segundo Maquiavel, ele merece essa posição simplesmente porque é mais confiável do que a nobreza ou os notáveis. De acordo com a distinção mencionada acima, entre os apetites das elites e os apetites populares, o povo não usará tal poder para dominar, mas apenas para se defender contra a dominação. Além disso, como o povo é menos apto do que a nobreza para usurpar a liberdade de uma república, ele estará mais vigilante em relação aos que são mais capazes de fazê-lo”. 
potência. Pois se nada há de permanente e estável entre os mortais, como nos dirá no sexto capítulo dos Discorsi, restará à política a função de, em seu movimento, criar as condições virtuosas para o próprio movimento.

Nesse sentido, em oposição ao ideário político tradicional, podemos identificar uma das grandes contribuições de Maquiavel ao pensamento político moderno na forma como, ao indicar a importância das leis e das instituições, pensa-as enquanto resultante do movimento de composição das forças sociais a elas anterior. Sobre esse ponto, estamos de inteiro acordo com Bignotto (1991, p. 96):

Portanto, o que diferencia Maquiavel dos humanistas cívicos não é o fato de ter descoberto o papel e a importância das leis, mas o de saber compreender que as leis são fruto do conflito infinito de desejos opostos. Isso explica por que Maquiavel nunca acreditou numa solução definitiva do conflito social. Os desejos, sendo não somente contraditórios, mas de naturezas diversas, não podem ser anulados por uma solução constitucional, nem mesmo pela mais perfeita a seus olhos: a republicana.

Todavia, é prudente ressaltarmos que, ao abordarmos o tema dos conflitos em Maquiavel, não estamos diante de uma realidade transparente capaz de nos desvelar, por sua própria existência, uma fenomenologia do político. Mais do que isso - e o famoso capítulo trinta e sete do Discorsi, sobre os tumultos engendrados em Roma pela legislação agrária, nos comprova, ao abordar o tema - Maquiavel nos mostra que os conflitos não podem ser reduzidos às suas manifestações imediatas e nem confundidos com a simples luta pela posse de bens ou com disputas ou querelas por cargos de poder ou territórios. Mais do que isso, parece- nos que, ao insistir em que nada, nem mesmo as boas leis podem controlar o caráter instável e movente da vida política, seu intuito resida em convidar-nos a outra apreciação da liberdade. É assim que, deixando pra trás os nefelibáticos cenários dos ideais reguladores - a cidade perfeita, a fundação ideal, a paz perpétua, etc. - sua argumentação envereda por identificar que o oposto a liberdade da república não é a tirania, mas sim a corrupção. E nesse sentido, em sua visada, a boa república não será aquela voltada ao horizonte regulador, mas sim a que abre, ininterruptamente, caminhos à ação dos homens na polis. Obrigando-nos a aceitar a trágica contingência do político, neste universo em contínuo movimento, serão as leis, é claro, referência importante, mas longe de nos descortinarem futuros gloriosos, apenas nos demonstrarão aquilo que de provisório e ambíguo se assinala sob o território político. E mais uma vez nos encontramos em acordo 
com a leitura proposta por Bignotto (1991, p. 102):

É verdade que não podemos falar de república onde não exista uma expressão jurídica da liberdade, onde o bem público não domina o interesse privado, onde não existe igualdade entre os homens; mas todas essas instituições, todas essas condições não são essências capazes de garantir a paz e a tranquilidade de um povo para sempre. A importância da corrupção está em que, colocando-se como o inverso da liberdade, desvela-nos a importância da ação humana na construção de toda sociedade. $\mathrm{O}$ estudo das leis livra-nos da ilusão constitucional, para nos obrigar a aceitar a contingencia do político.

Com efeito, o terreno epistemológico aberto por Maquiavel indica-nos que, ao pensarmos o político pela chave da liberdade, nossas referências não devem repousar sobre as leis ou as ilusões jurídicas, mas sim e fundamentalmente sobre a ação dos homens na polis. Sob esse ângulo, percebemos o tema da ação como via através da qual os homens experimentam a plenitude de sua condição política. Por seu intermédio, se criam e se transformam ao transformarem criativamente o mundo. Sob seu estandarte, a liberdade se afirma, a um só tempo, enquanto ato de resistência às forças da corrupção e também como veículo de criação de caminhos possíveis e horizontes concebíveis. Nesse sentido, se cada regime se estrutura na resposta política que oferece, enquanto solução - sempre provisória - aos conflitos que atravessam a sociedade, podemos concluir que é pela ação que se processa a invenção continuada da organização política. É em consideração a esse terreno que encontramos a relação proposta por Maquiavel entre a virtu e a fortuna. Aqui, a virtu designará a capacidade humana, demasiadamente humana, de se postar no mundo, de lêlo nos termos abertos por suas ocasiões e de sobre elas agir, mobilizando as forças necessárias para a elas resistir ou a elas transformar. Nesse processo, não devemos entender a virtu como um saber positivo e circunscrito por fórmulas ou leis destinadas a orientar a boa ação - o que não significa uma atitude, a priori, de desprezo pelos ensinamentos exemplares da tradição -, pois a virtu cria a si mesma em seus embates com a fortuna, incorporando assim, a mutabilidade do horizonte que a desafia.

Compreendemos agora que todas as formas políticas são o resultado das ações que as fundam e as conservam e é por essa constância da ação que adquirem sua identidade. Sabemos, no entanto, que a ação, que a eterna luta entre a virtu e a fortuna, não pode ser entendida através de um conjunto de proposições coerentes, fruto de um saber positivo. O sujeito político, no seu gesto de criação do presente, é sempre confrontado com a indeterminação do campo histórico, 
ele não pode conhecer jamais todas as etapas de seu caminho. Isso corresponde a dizer que nenhuma república pode identificar-se inteiramente com algum modelo teórico, que ela é sempre o resultado das ações que a fundam e conservam no tempo. (BIGNOTTO, 1991, p. 150)

Essa proposição da ação enquanto luta eterna entre a virtu e a fortuna tem, no penúltimo capítulo d'O príncipe, suas passagens mais exemplares. Nessas linhas, Maquiavel nos propõe que os dois conceitos somente fazem sentido e ganham relevância quando referidos um ao outro. Desacreditando a imagem da fortuna como força exterior ao mundo e que do alto de seus poderes dirige e governa os assuntos humanos, avança, fazendo-nos percebê-la enquanto gêmea da virtu, pois seus favores são sempre acompanhados pela exigência da ação. Em um desenho terrível e belo, compara a fortuna a um impetuoso rio que, quando em cheia, alaga as planícies, pondo ao chão tudo o que encontra no caminho de seu furioso curso. Todavia, quando suas águas cedem, a engenhosidade humana se lança na construção de barragens e diques, fazendo com que, nas próximas cheias, o rio abandone sua fúria e, calmamente, caminhe pelos canais inaugurados. Nesse sentido, convida-nos a pensar que o poder da fortuna encontra seu limite na ativa resistência organizada. Em sua visada, se é verdade que a fortuna seja árbitra de metade de nossas ações, ela ainda nos deixa governar a outra metade.

Dessa forma, sendo o espaço político um terreno estruturalmente instável e em constante mutação, longe de uma força externa e intangível, o principal inimigo do homem político é a sua própria natureza, quando resiste a adaptarse à maleabilidade do mundo e ao inesgotável fluxo do tempo. Por essa via, somos levados por Maquiavel a pensarmos a virtu como a capacidade humana de responder, pelo móvel da ação, aos desafios originados pela mudança das circunstâncias, pois sendo o tempo um puro e radical fluxo de um devir sem certezas, a virtu nos indica as possibilidades de com ele estabelecer acordos.

Creio que a razão disso, conforme o que se disse anteriormente, é que quando um príncipe se apoia totalmente na fortuna, arruína-se segundo as variações daquela. Também julgo feliz aquele que combina o seu modo de proceder com as particularidades dos tempos, e infeliz o que faz discordar dos tempos a sua maneira de proceder. [...] Disso dependem também as diferenças da prosperidade, pois se um se conduz com cautela e paciência e os tempos são favoráveis, o seu governo prospera e disso lhe advém a felicidade. Mas se os tempos e as coisas mudam, ele se arruína, porque não alterou o modo de proceder. Não se encontra homem tão prudente que saiba acomodar-se a isso, quer por não se poder desviar daquilo a que a natureza o impele, quer porque, 
tendo alguém prosperado num caminho, não pode resignar-se a abandoná-lo. Ora, o homem circunspecto, quando chega a ocasião de ser impetuoso, não o sabe ser, e por isso se arruína, porque se mudasse de natureza, conforme o tempo e as coisas, mudaria de sorte. (MAQUIAVEL, 1979, p. 104)

É sob esse espírito dúctil da ação que Maquiavel, nas páginas d'O príncipe, fará do César Bórgia o paradigma do homem virtuoso que tragicamente se confronta com o horizonte insondável e imprevisível do seu destino. Através dos exemplos do Duque, nos mostra que a fortuna pode auxiliar na fundação de principados novos, mas que seu concurso de nada serviria sem a força da virtu. Nas palavras de Bignotto, o exemplo de Bórgia nos faz ver que "uma boa fortuna não faz mais do que exigir uma virtu excepcional” (BIGNOTTO, 1991, p. 144). Nessa esteira, mobilizando o modelo do príncipe novo, vem à baila a ideia de que, no limite, a ação é a invenção, a partir do nada, de todas as redes de relações que constituirão e darão forma à sociedade. Sem o apoio dos costumes, a virtu do príncipe novo indica o seu êxito em, ao se defrontar com as rodas da fortuna, criar instituições e realidades inéditas.

Todavia, se estão em $O$ príncipe as mais célebres passagens a indicar a ação enquanto eterna luta entre virtu e fortuna, será nas páginas do Discorsi que encontraremos essa relação em sua radicalidade máxima. Abrindo o segundo livro, Maquiavel desafia as interpretações que apontavam a sorte e a fortuna como a causa mais importante das conquistas romanas. Contrariando essa perspectiva, em seu entender, se nunca houve república mais exitosa em termos de conquistas do que Roma, isso deve ser explicado pelo fato de nenhuma outra ter tido instituições tão apropriadas a esse fim. A virtude romana residiu na coragem de seus soldados, bem como na sabedoria com que a república soube formá-los. Nessas linhas, o exemplo romano parece querer nos revelar a fortuna como a ausência da virtu. Isso não significa, contudo, que a boa virtu possa nos oferecer o domínio completo e perfeito do fluxo temporal, mas sim, e ao contrário, de que é possível opor resistência à fortuna.

Dessa forma, no deslocamento entre O príncipe e o Discorsi, percebemos que, embora a figura do príncipe novo possa nos oferecer a imagem exemplar dos fundamentos da ação humana enquanto denominador máximo da política, a sua imagem não esgota toda a dimensão da ação, nem tampouco representa o mais sucedido caso da responsividade aos desafios postos pela mutabilidade do tempo. Ao contrário dos principados, na república, encontramos a reformulação da luta entre virtu e fortuna na reverberação, ressoada nas instituições, dos processos das lutas de classe que a atravessam. Nesse sentido, 
seja no cenário da guerra enquanto paradigma das relações externas, seja nos termos das relações internas, a eficácia da ação republicana é modulada pela peculiaridade imprimida na solução proposta para o conflito entre as classes sociais em luta. Por tal razão, diferentemente dos principados, a virtude da república reside no fato de que, em seu interior, os homens não agem exclusivamente como indivíduos apenas dotados de virtus particulares, mas sim como pessoa coletiva, coadunada com a virtu pública que a criou.

Percebe-se facilmente de onde nasce o amor à liberdade dos povos; a experiência nos mostra que as cidades crescem em poder e em riqueza enquanto são livres. [...] Contudo, mais admirável ainda é a grandeza alcançada pela república romana depois que foi libertada dos seus reis. Compreende-se a razão disto: não é o interesse particular que faz a grandeza dos Estados, mas o interesse coletivo. E é evidente que o interesse comum só é respeitado nas repúblicas: tudo o que pode trazer vantagem geral é nelas conseguido sem obstáculos. Se uma certa medida prejudica um ou outro indivíduo, são tantos os que ela favorece, que chega sempre a fazê-la prevalecer, a despeito das resistências, devido ao pequeno número de pessoas prejudicadas. [...] O contrário acontece numa monarquia: com frequência, o que o monarca faz em seu próprio interesse prejudica o Estado - e o que beneficia o Estado é nocivo aos interesses particulares do monarca. (MAQUIAVEL, 1979, p. 198)

Tendo por base essa passagem, podemos arriscar ser a diversidade dos cidadãos a fonte primária de conservação da boa fortuna da república, pois essa realidade sociologicamente multiforme a disporia a melhor se adaptar aos jogos das transformações temporais. Esse é um ponto crucial em nossa leitura, pois aqui o florentino nos apresenta uma concepção da política circunscrita pela potência multitudinal dos cidadãos da república. Em seu desafio perene em resistir aos ataques da fortuna, a estabilidade da forma política republicana encontra no sujeito político coletivo, na multidão de homens reunidos em prol da defesa de seus interesses comuns, a fonte e a razão de ser de sua virtu. Nesse sentido, no capítulo 58 do livro I do Discorsi, investindo contra a opinião de Tito Lívio, para quem nada haveria de mais ligeiro e inconstante do que a multidão de homens, Maquiavel considera que o erro do historiador romano residiria em generalizar enquanto comportamento natural da multidão aquela forma de comportamento que seria exclusiva da multidão sem lei, "[...] pois o defeito que os historiadores atribuem à multidão pode ser imputado aos homens, de modo geral - e aos príncipes em particular. Com efeito, todos a quem faltem leis para regular sua conduta podem cometer os mesmos erros que a multidão sem freio" (MAQUIAVEL, 1979, p. 179). Prosseguindo nessa linha 
argumentativa, Maquiavel defende que, se por um lado, tomarmos o exemplo de um príncipe e de um povo, ambos submetidos a postulados legais, veremos mais virtu na ação popular, por outro, pensando em ambos irrefreados pela lei, ainda assim, será no polo popular que encontraremos menos erros. Sob esse prisma indicativo de uma maior constância e virtude política da multidão, logramos o tema da personalidade coletiva enquanto força motriz da virtu republicana. É aqui, na esteira que leva da produção à efetivação política desse sujeito, que prosseguindo nosso diálogo com as interpretações ofertadas por Bignotto, observamos um novo fôlego ao tema da cidadania militar, proposto enquanto alfa e ômega do processo de constituição da virtu coletiva.

O tema da guerra é uma constante, quase obsessiva, em Maquiavel. Não apenas em sua reflexão teórica, mas também em sua prática política, esse tema acompanhou sua trajetória, tendo consumido muitos de seus esforços e alguns de seus anos no interior da segunda chancelaria florentina. Mas será, ao longo do segundo livro dos Discorsi, que Maquiavel nos apresentará uma visada mais sistemática acerca da importância política dos assuntos à guerra correlacionados.

A guerra é um elemento central da vida política de uma república, pois por seu móvel, articula-se o jogo da estabilização e conservação do poder, entendidos aqui como pontos de certo equilíbrio entre a conquista expansionista e a resistência a ser conquistada. Nesse sentido, a guerra, elo fronteiriço entre as dimensões externas e internas da vida política, atravessa estrutural e constitutivamente todos os momentos de produção da subjetividade coletiva. Sob esta embocadura, Maquiavel trançará em suas linhas uma íntima relação entre a virtu dos soldados e a vitalidade da república. Sabendo-se que guerras podem ter inícios calculados, mas, sempre, fins imprevistos, no capítulo $\mathrm{X}$ do segundo livro, adverte-se que, aquele que se lançar aos azares de uma campanha deve-o fazer com ciência plena de suas forças, levando-se em conta no cálculo, não apenas a disposição dos recursos financeiros, mas fundamentalmente a disposição dos homens em armas. Fazendo-se a guerra com ferros e não com ouro, as riquezas apenas acrescentam forças à cidade que possui boas armas, pouco podendo agregar à desarmada ${ }^{14}$.

14 Diz-nos Maquiavel: "Qualquer que seja a opinião geral, sustentarei, portanto, que os nervos da guerra não são o dinheiro, mas os bons soldados; e se o ouro não é suficiente para consegui-los, os bons soldados podem conseguir o ouro. Tivessem os romanos preferido fazer a guerra com o ouro, e não com o ferro, todos os tesouros não bastariam para conseguir o vasto território que conquistaram, ou para vencer os obstáculos com que se depararam. Mas como faziam a guerra com 
Com efeito, sendo a guerra um movimento imprevisível, posto que orbita em torno de eixos de imprevisibilidade, percebemos uma correlação entre esse tema e a indeterminação do espaço histórico-temporal, proposto aqui à guisa da fortuna. Diante desse cenário, percebemos ser a arte militar parte constitutiva e essencial do processo de resistência às contingências do mundo. Estando a guerra para a fortuna tal como arte militar para a virtu política, será somente através da virtu de bons soldados em responder aos ataques inimigos que encontraremos a propensão para uma paz duradoura. Em outros termos, Maquiavel nos convida aqui a pensarmos a paz não como um processo estático e a priori, mas sim como um movimento descortinado pela resposta virtuosa às contingências do mundo, movimento que, sob o signo ontológico da guerra, articula o circuito entre a paz, a política e a liberdade ${ }^{15}$. Nas palavras de Bignotto (1991, p. 157), "a grande sabedoria dos romanos foi, então, nem tanto a de saber fazer a guerra, mas a de ter reconhecido o seu caráter universal”.

Política e guerra, anverso e reverso de uma mesma moeda cunhada sob o curso da ação, o que nos fica claro em Maquiavel é a impossibilidade de circunscrevermos o universo da política aos limites de uma razão inscrita pela fria letra da lei. Tal como um movimento sobre o movimento, a estabilidade de um regime político deve ser entendida como a resposta especular que oferta a dimensão dos conflitos. Há assim uma imbricada relação na república entre a sua dimensão exterior, esculpida no movimento pendular da conquista à resistência, e os desafios da conservação próprios à sua dimensão interior, na qual, politicamente, se oferecem soluções possíveis aos conflitos de classe. Mesmo a operar em dimensões e temporalidades distintas, nos avizinhamos da ideia de que a política é gêmea da guerra, pois se há diferenciações entre o modo de preparação para o combate e o modo de organização dos conflitos sociais internos, essas diferenças serão, no máximo, de escalas, mas não de essência.

o ferro, nunca lhes faltou o ouro, pois os povos que os temiam iam até eles levando-lhes suas riquezas" (MAQUIAVEL, 1979, p. 222).

15 Essa é uma das principais heranças que Maquiavel, este agudíssimo florentino, delegará a Baruch Spinoza. Pensando uma equação triangular entre direito, coletividade e potência, na qual resultará a proposição do político enquanto potência da multidão e não potência subtraída à multidão, em seu Tratado político, Spinoza nos expõe que "uma cidade que não pega em armas unicamente pelo terror que os paralisa deve-se dizer, não que aí haja paz, mas antes que a guerra aí não tem lugar. Pois a paz não é ausência de guerra. É uma virtude que nasce da força da alma, e a verdadeira obediência é uma vontade constante de executar tudo aquilo que deve ser feito segundo o decreto comum da cidade. Do mesmo modo, uma cidade em que a paz não possui outra base senão a inércia dos súditos, os quais se deixam conduzir como um rebanho, e não são habituados senão com a servidão, merece mais o nome de solidão do que de cidade" (SPINOZA, 1973b, p.328). 
Por trás do continuum da guerra à política, o que Maquiavel nos revela em seu exame sobre a república romana é que a eficácia demonstrada na resposta aos ataques inimigos não pode ser pensada em independência à constituição de um certo módulo de tomada de decisões impresso em resposta ao movimento dos conflitos sociais. De tal sorte que o que se descortina aqui é uma íntima relação entre a bravura e o ímpeto com que os soldados se lançam à aventura do combate e as possibilidades abertas à participação nos assuntos políticos comuns. Sobre esse ponto, fazendo um cruzamento entre Maquiavel, o político florentino, e Maquiavel, o teórico renascentista do republicanismo, são esclarecedoras as palavras de Bignotto:

O elogio da infantaria é, nesse sentido, exemplar. Durante suas experiências como comissário, Maquiavel pode constatar como é difícil formar um corpo de infantaria. Isso não se deve à natureza dos homens, mas à natureza de suas relações com o Estado. Podemos concluir que a organização de uma milícia popular é o momento em que melhor se constata a importância do elemento popular na criação de um Estado forte. A guerra é, desse ponto de vista, uma experiência privilegiada, pois é a expressão da forma mais radical de participação do povo nos negócios da cidade. Essa questão vinha sendo levantada desde Bruni, mas ficara sem resposta, uma vez que o humanista ainda via na milícia um instrumento de controle aristocrático da vida política. A descoberta de Maquiavel não é, portanto, da importância da boa milícia, mas sim de que uma boa milícia exige uma forma democrática de governo. (BIGNOTTO, 1991, p. 161)

Enquanto experiência privilegiada da política, ao abordar o tema da guerra Maquiavel nos revela a produção da virtu republicana como o corolário imediato dos processos democráticos de participação política. Contudo, se a apreciação do caso romano nos desvenda ser a defesa da pátria o principal móvel engendrado por aquela sociedade para geração de um maior grau de participação popular nos assuntos concernentes aos negócios e destinos da cidade, não devemos, inocentemente, hipostasiar esse meio, tornando-o regra de uma eventual ciência positiva do político. Pois aqui, o cerne da questão não é o meio ou vetor em si - no caso, a defesa militar da cidade -, mas sim o resultado por ele gerado, ou seja, a criação contínua do político a partir da produção do sujeito político coletivo. Não se trata, assim, de uma sobrevalorização das formas políticas, mas sim de conteúdos e processos que, postos em curso, politicamente atravessam-nas e as redefinem. Nessa esteira, mais uma vez reencontramos em Maquiavel a ideia de que a defesa da boa república não se resume ao seu complexo institucional-legal. Ao contrário, 
caudatária da virtu popular em ato, a boa república é aquela que, inaugurando espaços de participação pública, nos convida à apreciação da experiência ativa da política como via, por excelência, de produção dos horizontes da liberdade coletiva.

\section{REFERÊNCIAS}

BIGNOTTO, Newton. Maquiavel Republicano. São Paulo: Ed. Loyola, 1991.

CASTORIADIS, Cornelius. A descoberta do Abismo. Folha de São Paulo, São Paulo, 29 fev. 2004. Disponível em: http://www1.folha.uol.com.br/fsp/mais/fs2902200409.htm. Acesso em: 13 mai. 2014.

COSTA, Alexandre. Heráclito: Fragmentos contextualizados. Algés: Ed. Difel, 2002.

COSTA, Jean Gabriel Castro. Maquiavel e o Trágico. 2010. Tese (Doutorado em Ciência Política) - Universidade de São Paulo, São Paulo, 2010. Disponível em: http://www.teses.usp.br/teses/disponiveis/8/8131/tde-09022011-125526/ptbr.php. Acesso em: 01 jan. 2014.

DELEUZE, Gilles. Nietzsche e a Filosofia. Porto: Ed. Res, 2001.

HESÍODO. Teogonia: a origem dos deuses. São Paulo: Ed. Iluminuras, 1995.

MAQUIAVEL, Nicolau. Discursos Sobre a primeira década de Tito Lívio. Brasília: Ed. UNB, 1978.

O príncipe, São Paulo: Ed. Abril cultural, 1979.

MCCORMICK, John. Machiavelli against Republicanism: On the Cambridge School's "Guicciardinian Moments". Political Theory, V. 31, N. 5, pp. 615-643, 2003.

. Democracia maquiaveliana: Controlando as elites com um populismo feroz. Revista Brasileira de Ciência Política, n. 12, Brasília, pp. 253-298, 2013.

POCOCK, John G. A. The Machiavellian Moment: Florentine political thought and atlantic republican tradition. New Jersey: Press Princeton University, 1975. 
SILVA, Ricardo. República e democracia em Maquiavel. In: ENCONTRO ANUAL DA ANPOCS, 32., 2008, Caxambu. Disponível em: http://portal.anpocs.org/portal/ index.php? option=com_docman\&task=doc_view\&gid=2706\&Itemid=230. Acesso em: $10 / 01 / 2014$.

SPINOZA, Baruch. Tratado político. São Paulo: Ed. Abril Cultural, 1973.

\title{
DE LA VERITÀ EFFETUTUALE A LA LIBERA LIBERTÀ O CONFLITO Y LIBERDAD EN MAQUIAVELO
}

Resumen: Partindo del debate com el campo del Republican revival, este artículo tiene por objetivo reflexionar acerca del significado del tema de la libertad en el pensamiento político de Nicolás Maquiavelo. Defendiendo que el pensamiento de Maquiavelo tiene sus raíces en una articulación entre la cultura trágica griega y la proposición de una dinámica política democrática, interpretaremos la libertad como la resultante de un juego que define a las instituciones políticas como locus de responsividad a las demandas inauguradas por los conflictos que estructuran la vida social.

Palabras-clave: Maquiavelo. Conflitos sociales. Liberdad.

\section{FROM THE VERITÀ EFFETUTUALE TO THE LIBERA LIBERTÀ OR CONFLICT AND LIBERTY IN MACHIAVELLI}

\begin{abstract}
This article aims to reflect about the meaning of freedom theme in the political thought of Niccolo Machiavelli based on the discussion with the Republican Revival field. Through of the argument that Machiavelli's thought has its roots in a articulation between Greek tragic culture and the proposition of a dynamic of democratic politics, we will interpret freedom as resultant of a game that defines the political institutions as a responsiveness locus to the demands inaugurated by one social life structured around the conflicts.
\end{abstract}

Key-words: Machiavelli. Social Conflicts. Freedom. 